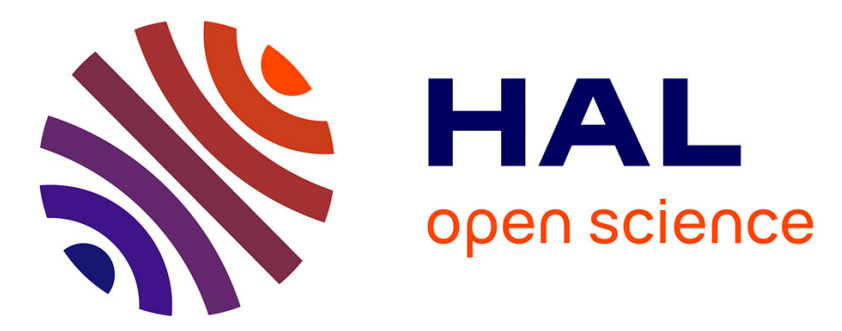

\title{
A novel radiocarbon dating technique applied to an ice core from the Alps indicating late Pleistocene ages
}

Theo M. Jenk, Sönke Szidat, David Bolius, Michael Sigl, Heinz W. Gäggeler, Lukas Wacker, Matthias Ruff, Carlo Barbante, Claude F. Boutron, Margit Schwikowski

\section{To cite this version:}

Theo M. Jenk, Sönke Szidat, David Bolius, Michael Sigl, Heinz W. Gäggeler, et al.. A novel radiocarbon dating technique applied to an ice core from the Alps indicating late Pleistocene ages. Journal of Geophysical Research, 2009, 114, pp.D14305. 10.1029/2009JD011860 . insu-00420844

\section{HAL Id: insu-00420844 https://hal-insu.archives-ouvertes.fr/insu-00420844}

Submitted on 10 Mar 2021

HAL is a multi-disciplinary open access archive for the deposit and dissemination of scientific research documents, whether they are published or not. The documents may come from teaching and research institutions in France or abroad, or from public or private research centers.
L'archive ouverte pluridisciplinaire HAL, est destinée au dépôt et à la diffusion de documents scientifiques de niveau recherche, publiés ou non, émanant des établissements d'enseignement et de recherche français ou étrangers, des laboratoires publics ou privés. 


\title{
A novel radiocarbon dating technique applied to an ice core from the Alps indicating late Pleistocene ages
}

\author{
Theo M. Jenk, ${ }^{1,2,3}$ Sönke Szidat, ${ }^{1,2}$ David Bolius, ${ }^{2}$ Michael Sigl, ${ }^{1,2}$ Heinz W. Gäggeler, ${ }^{1,2}$ \\ Lukas Wacker, ${ }^{4}$ Matthias Ruff, ${ }^{1,2}$ Carlo Barbante, ${ }^{5,6}$ Claude F. Boutron, ${ }^{7}$ \\ and Margit Schwikowski ${ }^{2,8}$
}

Received 5 February 2009; revised 28 April 2009; accepted 6 May 2009; published 24 July 2009.

[1] Ice cores retrieved from high-altitude glaciers are important archives of past climatic and atmospheric conditions in midlatitude and tropical regions. Because of the specific flow behavior of ice, their age-depth relationship is nonlinear, preventing the application of common dating methods such as annual layer counting in the deepest and oldest part. Here we present a new approach and technique, allowing dating of any such ice core at arbitrary depth for the age range between $\sim 500$ years B.P. and the late Pleistocene. This new, complementary dating tool has great potential for numerous ice core related paleoclimate studies since it allows improvement and extension of existing and future chronologies. Using small to ultrasmall sample size ( $100 \mu \mathrm{g}>$ carbon content $>5 \mu \mathrm{g})$ accelerator mass spectrometry, we take advantage of the ice-included, water-insoluble organic carbon fraction of carbonaceous aerosols for radiocarbon $\left({ }^{14} \mathrm{C}\right)$ dating. Analysis and dating of the bottom ice of the Colle Gnifetti glacier (Swiss-Italian Alps, $45^{\circ} 55^{\prime} 50^{\prime \prime} \mathrm{N}, 7^{\circ} 52^{\prime} 33^{\prime \prime} \mathrm{E}$, $4455 \mathrm{~m}$ asl) has been successful in a first application, and the results revealed the core to cover most of the Holocene at the least with indication for late Pleistocene ice present at the very bottom.

Citation: Jenk, T. M., S. Szidat, D. Bolius, M. Sigl, H. W. Gäggeler, L. Wacker, M. Ruff, C. Barbante, C. F. Boutron, and M. Schwikowski (2009), A novel radiocarbon dating technique applied to an ice core from the Alps indicating late Pleistocene ages, J. Geophys. Res., 114, D14305, doi:10.1029/2009JD011860.

\section{Introduction}

[2] Ancient ice has been extracted and analyzed from polar ice sheets for more than four decades, providing records of past climatic conditions on a hemispheric or even global scale [e.g., EPICA Community Members, 2004; Brook, 2005]. Ice cores recovered from high-altitude glaciers in midlatitude, subtropical, and tropical regions do not reach as far back in time. Nevertheless, they are important archives, containing information about regional climate variability in an area where the majority of the world's population lives and coupled ocean-atmosphere phenomena

\footnotetext{
${ }^{1}$ Department of Chemistry and Biochemistry, University of Bern, Bern, Switzerland.

${ }^{2}$ Paul Scherrer Institut, Villigen PSI, Switzerland.

${ }^{3}$ Now at Centre for Ice and Climate, Niels Bohr Institute, University of Copenhagen, Copenhagen, Denmark.

${ }^{4}$ Institute for Particle Physics, ETH Zurich, Zurich, Switzerland.

${ }^{5}$ Environmental Sciences Department, University of Venice, Venice, Italy.

${ }^{6}$ Institute for the Dynamics of Environmental Processes, CNR, University Ca'Foscari of Venice, Venice, Italy.

${ }^{7}$ Laboratoire de Glaciologie et Géophysique de l'Environnement, UMR 5183, University Joseph Fourier of Grenoble, CNRS, Saint-Martin-d'Hères, France.

${ }^{8}$ Oeschger Centre for Climate Change Research, University of Bern, Bern, Switzerland.
}

Copyright 2009 by the American Geophysical Union. 0148-0227/09/2009JD011860 such as El Niño-Southern Oscillation (ENSO) and the monsoon system are most strongly expressed [Cecil et al., 2004; Thompson, 1996; Thompson et al., 1998, 2000]. The vicinity of these glaciers to anthropogenic emission sources has the additional potential to improve our understanding of natural and human induced forcing of the climate system, since it enables the study of substances with short atmospheric lifetimes of a few days, having nonuniform global distribution and highest concentrations closest to the sources (e.g., aerosols). In any case, a precise chronology is a prime requirement for each natural archive to allow for a meaningful interpretation of the information recorded. The most common method used for ice core dating is annual layer counting, which relies on seasonally varying signals and is supported by the identification of reference horizons such as volcanic layers [Thompson et al., 1998; Schwikowski et al., 1995; Schwikowski, 2004; Eichler et al., 2000; ColeDai et al., 1997]. For ice cores from high-altitude glaciers, strong ice flow induced layer thinning limits counting of annual layers in the best case to a couple of centuries and is not suitable for the oldest and deepest part, where individual years cannot be distinguished anymore. Because of complex bedrock geometry of such glaciers, indirect dating using physical ice flow models can also not be applied for the entire length of the core. The lack of an appropriate dating tool for this lowermost section can be overcome in certain cases by wiggle matching of the stable isotope 


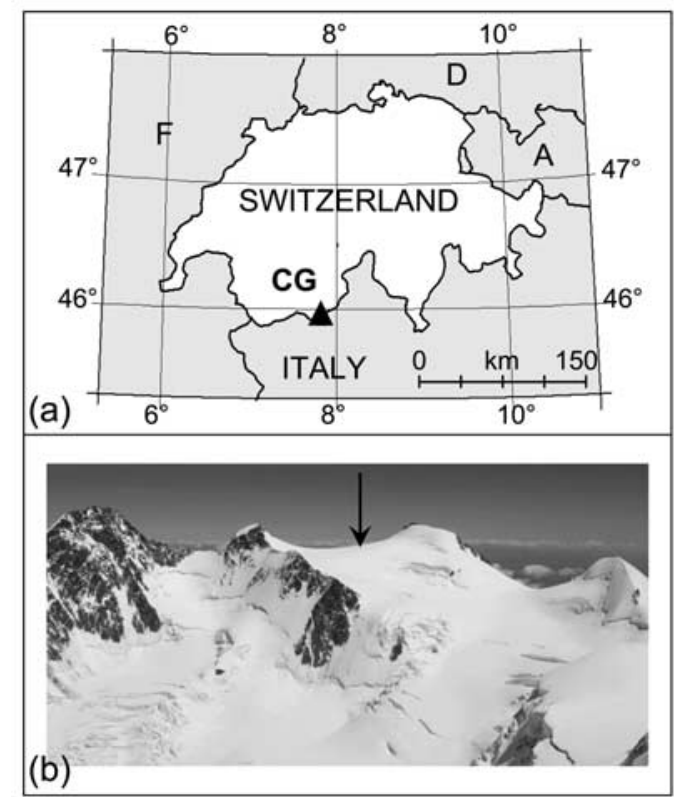

Figure 1. (a) Switzerland with its bordering countries Italy, Germany (D), Austria (A) and France (F) and the location of the Colle Gnifetti ( $\mathrm{CG}$, triangle). (b) View from the west to the Colle Gnifetti drilling site in 2003 (arrow) and surrounding summits (left to right: Dufourspitze, Zumsteinspitze, Signalkuppe, and Parrotspitze). Photo by K. Hassler.

records (i.e., stable isotopes of water $\delta \mathrm{D}$ or $\delta{ }^{18} \mathrm{O}$ and atmospheric $\delta^{18} \mathrm{O}_{\text {atm }}$ ), using the strong variation during the glacial-interglacial transition $(\sim 14,000-9000$ years B.P.) observed in polar ice cores [Thompson et al., 1995]. Accordingly, in this way dated ice core records will be strongly tied to the chronology of the polar ice cores. As a consequence however, this hinders the determination of the actual timing of events during the transition period for the site where the core was retrieved. Since the recognition of spatial shifts in timing for nonpolar regions is of high interest [e.g., Smith et al., 2005] important information is therefore lost. Furthermore, it is evident that a record reaching at least that far back in time is required to allow application of this dating method and even in this case, additional dating points are required between the age of the lowest annual layer counted and the age where the glacial/ interglacial transition occurs to account for changing accumulation rates. One should also keep in mind that not climate but artifacts such as diffusion processes can alter the signal of the stable isotopes of water close to the bedrock in the case of glaciers with a very high thinning [Keck, 2001]. Under such circumstances, dating by wiggle matching is hindered.

[3] Up to now, radiocarbon dating could only be applied on ice cores, when embedded insect fragments or plant debris were found [Thompson et al., 1998]. In contrast to such randomly occurring biogenic debris, carbonaceous particles, a major component of the atmospheric aerosol, are constantly removed from the atmosphere by precipitation and form integral part of the impurities found in glacier ice [e.g., Lavanchy et al., 1999; McConnell et al., 2007].
They are composed of organic carbon (OC) and elemental carbon (EC), which can be separated because of their specific thermal properties [Szidat et al., 2004a, 2004b; Jenk et al., 2007]. Before 1850 A.D., OC was of purely biogenic origin from vegetation emissions, since the combustion of fossil fuels was insignificant [Jenk et al., 2006]. OC thus reflects the ${ }^{14} \mathrm{C} /{ }^{12} \mathrm{C}$ ratio of the living biosphere at the time of photosynthesis, which makes it suitable for ${ }^{14} \mathrm{C}$ dating. In contrast, this seems not to be the case for the EC fraction and as a consequence also not for the total carbon (TC, the sum of OC and EC) [Jenk et al., 2006]. Among other reasons such as inbuilt radiocarbon ages from the combustion of aged organic material a methodical problem related to the high combustion temperatures required for the analysis of $\mathrm{EC}\left(650^{\circ} \mathrm{C}\right.$ compared to $340^{\circ} \mathrm{C}$ for OC) in combination with samples of high mineral dust content as encountered in the Alps cannot be excluded [Jenk et al., 2006]. Accordingly, our new approach was to extract the water-insoluble organic carbon fraction of the carbonaceous particles and use it for radiocarbon dating. Since this approach is not depending on the random finding of carbon debris (e.g., insects) it allows in principal the dating of any ice core at arbitrary depth using as many consecutive samples as needed, at the least for the age range between $\sim 500$ years B.P. and the late Pleistocene. However, in most cases when ancient carbon containing material is dated on the basis of the ${ }^{14} \mathrm{C} /{ }^{12} \mathrm{C}$ ratio determined with accelerator mass spectrometry (AMS), currently the most sensitive technique, this is conducted on milligram amounts of carbon. Therefore, one of the major challenges to this approach is the low content of organic carbon in glacier ice which requires analysis of much smaller samples with sizes below $100 \mu \mathrm{g}$ [Lavanchy et al., 1999; Jenk et al., 2006].

[4] To succeed with this novel dating approach the methods used had to be continually improved. New limits could be reached in the course of several studies related to the extraction of particles from the ice [Lavanchy et al., 1999; Jenk et al., 2006, 2007], the analysis of OC and EC concentrations using a thermal separation method in combination with ${ }^{14} \mathrm{C}$ analysis [Lavanchy et al., 1999; Szidat et al., 2004a; Szidat et al., 2004b; Jenk et al., 2006, 2007] and AMS technology [Synal et al., 2007; Ruff et al., 2007, 2009]. Here, we present a first application performed on an ice core from Colle Gnifetti (Monte Rosa, 45 $55^{\prime} 50^{\prime \prime} \mathrm{N}$, $7^{\circ} 52^{\prime} 33^{\prime \prime} \mathrm{E}, 4455 \mathrm{~m}$ asl), recovered in September 2003. The Colle Gnifetti is the highest glacier saddle in the Alps suitable for ice core studies (Figure 1). At this site great potential exists to find old ice because the (cold) glacier is frozen to the bedrock and the net annual snow accumulation rates are low because of preferential wind erosion of dry winter snow [Schwikowski, 2004].

\section{Methods}

\subsection{Sample Preparation}

[5] Nine core sections were analyzed for ${ }^{14} \mathrm{C}$ to obtain dating points also for the lowest part $(67.2-80.2 \mathrm{~m} / \mathrm{bed}-$ rock) of the Colle Gnifetti 2003 ice core (CG03). To use as little of the archive as feasible to establish the chronology, we tried to keep sample amounts the lowest possible at all times. Length and masses of these nine individual samples 
Table 1. Summary of the Colle Gnifetti 2003 Ice Core Samples ${ }^{\mathrm{a}}$

\begin{tabular}{|c|c|c|c|c|c|c|c|}
\hline Core Section & Depth (m) & Ice $(\mathrm{kg})$ & $\begin{array}{c}\text { AMS } \\
\text { Laboratory }\end{array}$ & $\begin{array}{c}\text { Carbon (OC) } \\
(\mu \mathrm{g})\end{array}$ & $\begin{array}{c}\text { \% Modern } \\
\text { Carbon (pMC) }\end{array}$ & $\begin{array}{c}{ }^{14} \text { C Date } \\
\text { (Years B.P.) }\end{array}$ & $\begin{array}{c}{ }^{14} \mathrm{C}_{\mathrm{cal}} \mathrm{Age}^{\mathrm{b}} \\
\text { (Years cal B.P.) }\end{array}$ \\
\hline $105 / 106$ & $67.2-68.5$ & 1.055 & EG0221 ${ }^{\mathrm{c}}$ & 17.1 & $94.7 \pm 4.3^{d}$ & $435 \pm 365^{\mathrm{d}}$ & $160-400$ \\
\hline 107 & $68.5-69.1$ & 0.500 & EG0099 & 7.3 & $97.4 \pm 5.1^{\mathrm{d}}$ & $210 \pm 420^{\mathrm{d}}$ & $330-660$ \\
\hline 109 & $69.8-70.5$ & 0.588 & EG0098 & 9.5 & $92.2 \pm 3.8$ & $650 \pm 330$ & $540-930$ \\
\hline 114 & $73.2-73.8$ & 0.902 & ET691 & 28.6 & $85.9 \pm 3.5$ & $1220 \pm 330$ & $920-1390$ \\
\hline 117 & $75.0-75.3$ & 0.904 & ET553 ${ }^{\mathrm{e}}$ & 33.1 & $80.5 \pm 2.9$ & $1740 \pm 290$ & $1370-1870$ \\
\hline 121 & $77.1-77.7$ & 0.816 & ET551 ${ }^{\mathrm{e}}$ & 26.8 & $78.4 \pm 2.8$ & $1950 \pm 290$ & $1750-2350$ \\
\hline 123 & $78.4-79.0$ & 0.949 & ET554 & 50.6 & $65.7 \pm 1.3$ & $3370 \pm 160$ & $3440-3830$ \\
\hline 124 & $79.0-79.6$ & 1.084 & ET692 & 20.1 & $40.1 \pm 2.7$ & $7340 \pm 540$ & $7600-9100$ \\
\hline 125 & $79.6-80.2$ & 0.927 & ET694 ${ }^{\mathrm{e}}$ & 61.5 & $8.8 \pm 5.4^{f}$ & $>13,100^{\mathrm{f}}$ & $>15,200^{\mathrm{f}}$ \\
\hline
\end{tabular}

${ }^{\mathrm{a}}$ Samples were radiocarbon dated using the extracted organic carbon (OC) for AMS analysis. Values are rounded; given absolute uncertainties indicate the $1 \sigma$ range.

${ }^{\mathrm{b}}$ All core sections were calibrated with OxCal 3.10, except for 125 MCMC sampling was used (see section 2.2 and Figure 2).

${ }^{\mathrm{c}}$ MICADAS AMS system with gas ion source (analysis of $\mathrm{CO}_{2}$ ) (see section 2.1).

${ }^{\mathrm{d}}$ Indistinguishable from modern values within a $1 \sigma$ range.

eTANDY AMS system (analysis of graphite processed from $\mathrm{CO}_{2}$ ) (see section 2.1).

${ }^{\mathrm{f}}$ Note that measured value and uncertainty are of similar size. Therefore, ages are shown as upper $2 \sigma$ limits only [Stuiver and Polach, 1977] (see section 2.2).

thus varied between 0.3 and $1.4 \mathrm{~m}$ and $500-1084 \mathrm{~g}$ ice, respectively. From each sample, the water-insoluble organic carbon fraction was extracted by filtration and the organic residue (varying between 7.3 and $61.5 \mu \mathrm{g}$ carbon) was subsequently processed for ${ }^{14} \mathrm{C}$ AMS analysis. See Table 1 for more details to the individual samples.

[6] The method we applied to separate the organic (OC) and elemental carbon (EC) fraction of carbonaceous particles prior to the analysis of microgram amounts of carbon by ${ }^{14} \mathrm{C}$ AMS was initially developed for ambient aerosol samples [Szidat et al., 2004a, 2004b, 2006]. Jenk et al. [2006, 2007] describe the adaptation for ice samples, including complete methodological details in accordance to this study. Here, the overall procedure is summarized in short: Ice cores were cut into pieces and decontaminated by removal of outer layers in a cold room $\left(-20^{\circ} \mathrm{C}\right)$ using a stainless steel band saw. For further decontamination, the derived and still frozen samples were additionally rinsed with ultrapure water (MilliQ, $18 \mathrm{M} \Omega \mathrm{cm}^{-1}$ quality) in a laminar flow box. After melting, the water-insoluble carbonaceous particles contained in the ice were collected by filtration and the filters were combusted in steps at $340^{\circ} \mathrm{C}$ and $650^{\circ} \mathrm{C}$ to separate $\mathrm{OC}$ from EC. The evolved $\mathrm{CO}_{2}$ was cryogenically trapped and its volume determined manometrically. A $2-5 \%$ aliquot for ${ }^{13} \mathrm{C}$ isotope ratio mass spectrometry (IRMS, Delta Plus XL with Thermo-Finnigan Gas Bench- and Precon-inlet system) was separated and flame sealed in an evacuated glass tube. The remaining $\mathrm{CO}_{2}$ was sealed in a quartz tube for transformation to filamentous carbon (graphitization) using manganese granules and cobalt powder prior to final ${ }^{14} \mathrm{C}$ AMS analysis at the ETH AMS facility ("TANDY," $500 \mathrm{kV}$ pelletron compact AMS system) [Synal et al., 2000].

[7] Note that AMS analysis was accomplished in four different series between December 2005 and May 2007. To assure the quality of the measurements and to monitor the performance of the AMS system, measurements of blanks and standards were performed during each AMS campaign. A new AMS system ("MICADAS," $200 \mathrm{kV}$ compact radiocarbon AMS system with gas ion source) was used for samples analyzed in the last two series (see Table 1) and made initial processing of gaseous $\mathrm{CO}_{2}$ to solid graphite AMS targets unnecessary, thus decreasing the number of preparation steps and the AMS procedural blank contribution from $750 \mathrm{ng}$ to $55 \mathrm{ng}$ [Synal et al., 2007; Ruff et al., 2007, 2009]. Performance tests for both AMS systems were run using different reference materials. Reproducible values in good agreement with the consensus values could be achieved for both systems, i.e., for solid and gaseous targets [Jenk et al., 2007; Ruff et al., 2007, 2009]. Blank measurements for the overall procedure of the method were continuously performed using artificial ice. This overall system blank was reproducible throughout the time period of analysis with a mean carbon mass of $1.5 \pm 0.8 \mu \mathrm{g}$ OC $(\mathrm{n}=20)$ and a pMC of $64 \pm 11(\mathrm{n}=9)$. This is consistent with the previously reported blank value of $1.3 \pm 0.6 \mu \mathrm{g} \mathrm{OC}$ and a pMC of $61 \pm 13$ [Jenk et al., 2007].

[8] The presented method and setup allows dating of any ice core in a reasonable amount of time and on a routine basis if comparable or higher aerosol concentrations than presented here are contained. Four ice samples a day could be processed, involving simultaneous measurement of OC and EC and preparation of both fractions for subsequent AMS analysis (no EC results shown here). One day was needed to produce all the standards and blanks required for AMS calibration and quality control of the overall procedure. Final AMS measurements took approximately $20 \mathrm{~min}$ per target.

\subsection{Calibration of ${ }^{14} \mathrm{C}$ Dates}

[9] All conventional ${ }^{14} \mathrm{C}$ ages were calibrated using the OxCal v3.10 software with the IntCal04 calibration curve [Bronk Ramsey, 2001; Reimer et al., 2004]. Taking advantage of the stratigraphic information contained in the ice core which allows assuming a sequence of samples to be in chronological order because of the underlying deposition process, the software implemented Markov chain Monte Carlo method (MCMC) could be applied [Bronk Ramsey, 2005]. With this method the constraint probability distributions for a group of items in a sequence were calculated using the well-defined calendar age of the Laki eruption as the youngest date in the sequence (see Figure 2). For the lowermost sample (core section 125, 79.6-80.2 m) a low yield resulted for the graphitization process and led to high final uncertainties. In accordance to the suggestions made by Stuiver and Polach [1977], only a conservative upper 




Figure 2. Calibration of the Colle Gnifetti OC derived ${ }^{14} \mathrm{C}$ dates using OxCal v3.10 [Bronk Ramsey, 2001; Reimer et al., 2004]. See Table 1 for data. Filled areas show the calculated constraint probability distributions of the calibrated ages using Bayesian statistics, i.e., constraint Markov Chain Monte Carlo sampling (MCMC). As indicated by the increasing ice section number on the $y$ axis, the samples can be assumed as a group of items in a sequence because of their chronological order of deposition and MCMC sampling (constraint "Sequence") can therefore be applied [Bronk Ramsey, 2005]. For the sequence presented, the well-defined calendar age of the Laki eruption (1783/1784 A.D.) was selected to represent the youngest date. The overall agreement index of the calibration using this approach is $115.9 \%$ which is well above $60 \%\left(\mathrm{~A}^{\prime} \mathrm{c}\right)$, the level below which reevaluation of the assumption should be performed. Agreement indices corresponding to the individual core sections are given in parentheses. For comparison, thin lines show the results derived from applying the basic standard calibration procedure (i.e., probability distributions without constraints). Adapted from OxCal v3.10.

age limit based on the defined ${ }^{14} \mathrm{C} /{ }^{12} \mathrm{C}$ ratio plus $2 \sigma$ was received for this sample and accordingly it was neither included in the MCMC sequence nor in the two-parameter model (see section 2.3).

[10] All radiocarbon derived dates were rounded and are presented as conventional radiocarbon ages (years B.P. = years before 1950 A.D.) or calibrated ${ }^{14} \mathrm{C}$ ages $\left({ }^{14} \mathrm{C}_{\mathrm{cal}}\right.$; years cal B.P.) with $1 \sigma$ range as defined by Stuiver and Polach [1977]. Ages in Table 2 and Figure 3 are presented as years before 2003 A.D.

\subsection{Two-Parameter Model}

[11] To determine a continuous depth-age relationship for the entire CG ice core, a two-parameter model was applied

Table 2. Summarized CG03 Ice Core Dating Points Compared to the Corresponding Model Derived Ages ${ }^{\mathrm{a}}$

\begin{tabular}{|c|c|c|c|c|c|}
\hline Depth (m) & $\begin{array}{c}\text { Depth } \\
\text { (m weq) }\end{array}$ & $\begin{array}{c}\text { Horizon (Year A.D.)/ } \\
\text { Ice Section }\end{array}$ & $\begin{array}{c}{ }^{14} \mathrm{C}_{\mathrm{cal}} \text { Ages } \\
\text { (Years Before 2003 A.D.) }\end{array}$ & $\begin{array}{c}2 p \text { Model } \\
\text { (Years Before 2003 A.D.) }\end{array}$ & $\begin{array}{c}\text { Number of } \\
\text { Years Contained } \\
\end{array}$ \\
\hline 18.85 & 10.49 & SD (1977) & & $27_{-2}^{+1}$ & \\
\hline 24.45 & 14.21 & ${ }^{3} \mathrm{H}(1963)$ & & $40_{-3}^{+2}$ & \\
\hline 29.21 & 17.73 & SD (1947) & & $53_{-4}^{+3}$ & \\
\hline 32.00 & 19.90 & SD (1936) & & $63_{-5}^{+4}$ & \\
\hline 37.31 & 24.32 & Katmai (1912) & & $84_{-7}^{+5}$ & \\
\hline 39.20 & 25.95 & SD (1901) & & $94_{-7}^{+6}$ & \\
\hline 53.52 & 38.81 & Laki (1783/1784) & & $208_{-19}^{+15}$ & \\
\hline $67.18-68.47$ & $51.09-52.25$ & $105 / 106$ & $330 \pm 120$ & $560_{-60}^{+50}$ & 60 \\
\hline $68.47-69.10$ & $52.25-52.82$ & 107 & $550 \pm 170$ & $610_{-70}^{+60}$ & 40 \\
\hline $69.77-70.49$ & $53.43-54.08$ & 109 & $790 \pm 200$ & $700_{-80}^{+70}$ & 50 \\
\hline $73.17-73.75$ & $56.49-57.01$ & 114 & $1210 \pm 240$ & $1050_{-140}^{+120}$ & 90 \\
\hline $74.95-75.33$ & $58.09-58.54$ & 117 & $1670 \pm 250$ & $1420_{-200}^{+180}$ & 140 \\
\hline $77.11-77.65$ & $60.04-60.52$ & 121 & $2100 \pm 300$ & $2440_{-390}^{+360}$ & 430 \\
\hline $78.36-78.95$ & $61.16-61.69$ & 123 & $3690 \pm 200$ & $\begin{array}{l}4250_{-760}^{+740} \\
\end{array}$ & 1,540 \\
\hline $78.95-79.60$ & $61.69-62.28$ & 124 & $8400 \pm 750$ & $6810_{-1340}^{+1350}$ & 5,040 \\
\hline $79.60-80.18$ & $62.28-62.79$ & 125 & $>15,200^{\mathrm{b}}$ & $19,100_{-4500}^{+4800}$ & $(\infty)$ \\
\hline
\end{tabular}

${ }^{\mathrm{a}}$ Presented are the values of the assigned single horizons (calendar dates), the mean values of the calibrated ${ }^{14} \mathrm{C}$ ages given in Table 1 (here not in years cal B.P. but in years before 2003 A.D., rounded, $1 \sigma$ range) as well as the two-parameter model derived ages (rounded, $1 \sigma$ error estimates) calculated for the corresponding depth. SD denotes Saharan dust events, ${ }^{3} \mathrm{H}$ denotes the 1963 Tritium peak, and volcanic eruptions are indicated by their names. The modelderived numbers of years contained in each core section are given in addition. Find a graphic display of the data in Figure 3.

${ }^{\mathrm{b}}$ Upper $2 \sigma$ limit (see Table 1). 




Figure 3. Two-parameter model [Thompson et al., 1990] derived depth-age relationship for the CG03 ice core. The model is based on distinct horizons from Saharan dust events as well as volcanic layers, the tritium signal from nuclear weapon tests (indicated with calendar dates, A.D.), and calibrated ${ }^{14} \mathrm{C}$ ages $\pm 1 \sigma$ (years before 2003 A.D.) derived from the analysis of water-insoluble carbonaceous aerosols (i.e., OC) which were extracted from the ice.

[Thompson et al., 1990]. The model can be expressed by the following equation:

$$
T(z)=\frac{H}{b \cdot p}\left(\left(1-\frac{z}{H}\right)^{-p}-1\right)
$$

where $T(z)$ is the age (years) as a function of depth $z$ in meter water equivalent (m weq), $H$ the given glacier thickness ( $\mathrm{m}$ weq), $b$ the accumulation rate per year (m weq) and $p$ the thinning parameter (dimensionless). The model was fit to the available dating points (see section 3) by varying the accumulation rate $b$ and the thinning parameter $p$ using a least squares approach. The radiocarbon dates were derived from ice samples of around $60 \mathrm{~cm}$ in length and thus do represent an average age. According to that, as depth $z$ the section center was used for the fitting. To avoid overweighting of edge points, the logarithmic values of the ages summarized in Table 2 were utilized. For an error estimation of the maximum deviation of the modeled age scale, the upper and lower ${ }^{14} \mathrm{C}_{\mathrm{cal}} 1 \sigma$ limits were used instead (Table 2). Note that the result for the oldest sample (core section $125,79.6-80.2 \mathrm{~m}$ ) defined by an upper age limit only was not included in any of the model calculations (see section 2.2).

\section{Results}

[12] The calibrated ${ }^{14} \mathrm{C}$ ages of nine samples analyzed allowed dating of the oldest ice at Colle Gnifetti for the first time. Ages of 7600-9100 years cal B.P. for the second lowest sample and more than 15,200 years cal B.P. for the lowermost sample (core section 125) were obtained. However, the latter value has high uncertainty caused by a poor technical performance of the ${ }^{14} \mathrm{C}$ measurement (see Table 1). Even though it is in agreement with the age prediction from the thinning model (see next paragraph), we consider it to be indicative only for the existence of late Pleistocene ice in the European Alps. Calibrated radiocarbon ages are questionable for ages $<500$ years B.P., especially when uncertainties are relatively large (see the "probability distributions without constraints" derived for the youngest samples shown in Figure 2). This is due to a flattening of the radiocarbon calibration curve in this time period, leading to multiple solutions of possible ages. Nevertheless, the modern pMC values measured for the two youngest samples indicate that the possibility of a significant systematic shift to older ages can be excluded. The ${ }^{14} \mathrm{C}_{\mathrm{cal}}$ dates are derived from $\mathrm{OC}$ which has been extracted from ice samples of $\sim 60 \mathrm{~cm}$ in length. Therefore, they do represent an averaged age. An inhomogeneous distribution of carbonaceous particles within the analyzed core sections could potentially influence the modeled final dating discussed below. Here, such an effect was found to be negligible ( $\leq 10 \%$ of the given $1 \sigma$ uncertainty to final two-parameter model results), assuming comparable distribution for OC and major ions which were analyzed with higher resolution. However, since the precision of the method is supposed to increase in the future, the shortest possible (i.e., available) ice samples should generally be favored.

[13] To obtain a continuous depth-age relationship the two-parameter model described in section 2.3 was used to fit the derived ${ }^{14} \mathrm{C}_{\mathrm{cal}}$ results (with exception of core section 125 ) and the dating points derived from reference horizons which were supported supplementary by annual layer counting possible for the first 240 years and independent ${ }^{210} \mathrm{~Pb}$ dating (not shown) [Gäggeler et al., 1983]. The corresponding results are summarized in Table 2 and the obtained continuous depth-age relationship is displayed in Figure 3. According to the model, the CG03 core covers the entire Holocene and reaches an age $>14,600$ years B.P. at the bottom (i.e., $30 \mathrm{~cm}$ above bedrock the derived age is $19,100_{-4500}^{+4800}$ years B.P.). The model derived age for the bottom ice supports the independently (since it was excluded from model calculations) derived ${ }^{14} \mathrm{C}_{\mathrm{cal}}$ age for this section (core section 125), adding evidence for the presence of Pleistocene ice. The reference horizons used were the maximum in the tritium activity peak in the year 1963 A.D. from the nuclear weapons tests [Eichler et al., 2000], the volcanic eruptions of Laki and Katmai, and historically documented Saharan dust events (Table 2). Multiple regression analysis with a least squares approach, i.e., a nonlinear least squares fit between the model and the logarithmically transformed data points, was carried out to obtain ideal values for the model variables $b$ and $p$ (accumulation and thinning, respectively). Model parameters with $H=62.79 \mathrm{~m}$ weq resulted with $b=0.454 \pm 0.033 \mathrm{~m}$ weq $\mathrm{a}^{-1}$ and $p=$ $0.867 \pm 0.048$ (adjusted $r^{2}=0.989$ ). For the error estimation, the best fit sets of parameters for the upper and lower confidence limits of the calibrated ${ }^{14} \mathrm{C}$ ages were $b=0.433 \pm$

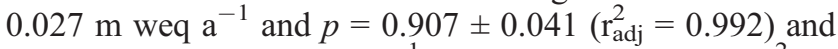
$b=0.486 \pm 0.056 \mathrm{~m}^{2}$ weq a $\mathrm{a}^{-1}$ and $p=0.821 \pm 0.077\left(\mathrm{r}_{\text {adj }}^{2}=\right.$ 0.971 ), respectively. Different from real conditions, the applied model assumes constant accumulation. The obtained value of $0.45_{-0.02}^{+0.03} \mathrm{~m}$ weq a $\mathrm{a}^{-1}$ is in good agreement with the low average accumulation rate of the study site $\left(0.46 \pm 0.08 \mathrm{~m}\right.$ weq $\left.\mathrm{a}^{-1}\right)$ which was observed in the uppermost 30 annual layers where the thinning effect is negligible. The good fit between the upper part of the core 

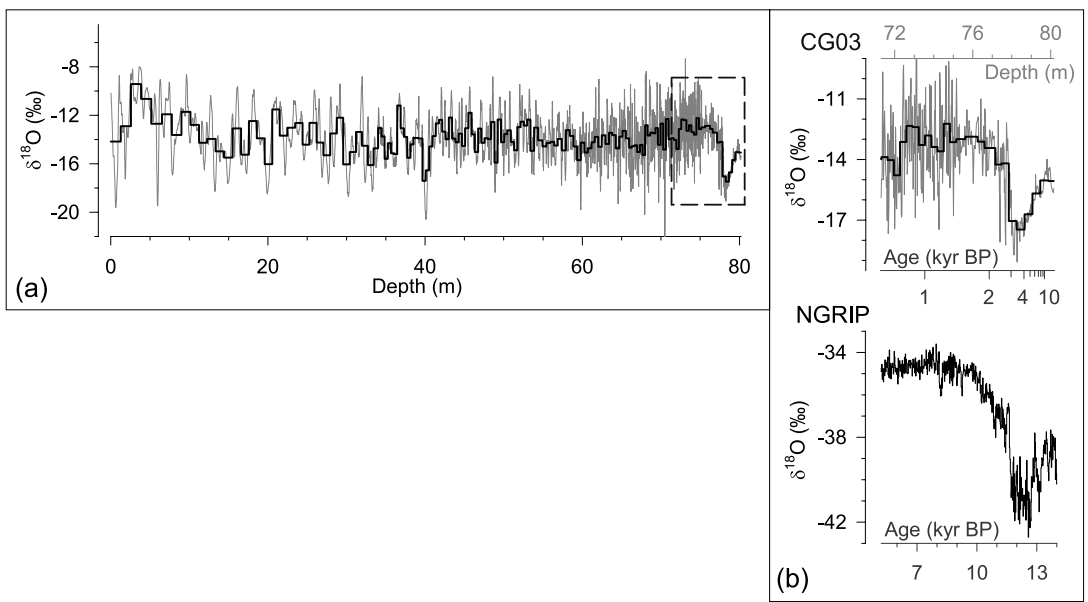

Figure 4. (a) The $\delta^{18} \mathrm{O}$ (SMOW) record of the $\mathrm{CG} 03$ ice core (gray) superimposed by a 20 point (i.e., 20 samples) average to guide the eye (black). The dashed frame indicates the section enlarged in Figure $4 \mathrm{~b}$. (b) The self-evident $\delta^{18} \mathrm{O}$ wiggle matching of the CG03 with the NGRIP record (20 year means) [Vinther et al., 2006; Rasmussen et al., 2006]. Note the discrepancy in the age scales between the two records. In the case of this study site the $\delta^{18} \mathrm{O}$ depletion seems not to correspond with the glacial/ interglacial climate transition. This is in agreement with previous results based on the additional measurement of atmospheric $\delta^{18} \mathrm{O}_{\mathrm{atm}}$ [Keck, 2001]. NGRIP data are available at http://www.iceandclimate. nbi.ku.dk/data/.

where dating relies on well established methods and the lower part where calibrated radiocarbon ages are increasing continuously with depth as one would expect also adds confidence in the new dating tool. An important strength of the described new radiocarbon dating method is the possibility to detect outliers caused by problems during sample preparation or analysis. The observed OC/EC ratio as well as the measured ion current in relation to the amount of carbon in the sample contains the necessary information [Jenk et al., 2007]. The access to multiple samples additionally allows detection of outliers in the measured sequence (stratigraphic outliers), removing the dependency on a result from singular analysis as it is encountered by the random finding of only one piece of organic material.

[14] Figure 4 presents the stable oxygen isotope record $\left(\delta^{18} \mathrm{O}\right.$ values in \%o relative to Standard Mean Ocean Water (SMOW)) of the Colle Gnifetti 2003 ice core in which a drop to more depleted isotopic ratios was observed close to bedrock ( $\sim 78 \mathrm{~m}$ depth). This feature has strong resemblance to the sections in the Greenland ice core records representing the abrupt climate shifts that terminated the last glacial (see Figure 4b). The very distinct signal of the transition from the Younger Dryas into the Holocene for example could be dated with high accuracy to an age of 11,650 years B.P. [North Greenland Ice Core Project members, 2004; Steffensen et al., 2008]. However, radiocarbon dating assigns an age of only $\sim 3$ ka B.P. to the pronounced drop in the CG03 $\delta^{18} \mathrm{O}$ profile. Several ice cores were drilled at Colle Gnifetti in the past and $\delta^{18} \mathrm{O}$ showed comparable depletion in the deepest part of these cores if bedrock was reached. In agreement with our results, atmospheric $\delta^{18} \mathrm{O}_{\mathrm{atm}}$ measurements [e.g., Bender et al., 1994] performed on one of these cores to distinguish between Late Glacial and Holocene ice gave evidence that the observed signal in the stable oxygen record of water does not correspond to the glacial/interglacial climate tran- sition [Keck, 2001]. Instead, the exceptional strong thinning at Colle Gnifetti might cause a pressure induced $\delta^{18} \mathrm{O}$ depleted liquid front along shear zones which was considered to explain the observed depression in the lowermost part of the core. In any case, even though our dating is in line with previous results, i.e., not attributing the shift in the $\delta^{18} \mathrm{O}$ record to the glacial/interglacial climate transition [Keck, 2001] the interpretation and understanding of the Colle Gnifetti records of stable isotopes of water are still incomplete and need further investigation.

[15] In order to validate the new dating method, we made first attempts to analyze ice samples from Greenland (GRIP) previously well dated by independent methods [Vinther et al., 2006]. Concentrations of carbonaceous particles are approximately ten times lower in Greenland than in ice from high-elevation glaciers which demands preparation of larger ice samples. Such samples generally have a surface to mass ratio which is less favorable in terms of contamination risk due to the limited availability of pieces with a large cross-section size. The carbon containing liquid which is used to stabilize the borehole in the deep drilling in combination with microcracks and long storage time makes analysis of such samples significantly more difficult compared to the samples from Colle Gnifetti. One sample could be analyzed and resulted in a value somewhat underestimating the independently defined age (GRIP, depth: $1308.45 \mathrm{~m}$, age: $7933 \pm 42$ years B.P.; measured: $6900 \pm 500$ years cal B.P. $(2 \sigma))$. GRIP data are available at $\mathrm{http}: / / \mathrm{www}$.iceandclimate. nbi.ku.dk/data/. However, because of the above reasons this single result cannot be considered to validate the method. Since the properties of Greenland samples present a specific challenge not related to the samples we are aiming for, no further efforts have been made. Instead, we also applied the new dating technique to an ice core from Nevado Illimani (Bolivian Andes, $16.62^{\circ} \mathrm{S}, 67.77^{\circ} \mathrm{W}$ ) [Knüsel et al., 2003]. At this site, two parallel ice cores (A: $136.7 \mathrm{~m}$; B: $138.7 \mathrm{~m}$ ) 
were drilled in 1999. First dating models based on annual layer counting, the signal from electrical conductivity measurement (ECM) and volcanic layers exist for both cores and are in perfect agreement for the top 90\% [Knüsel et al., 2003]. For core A, Ramirez et al. [2003] described the dating further back in time to the Last Glacial applying $\delta^{18} \mathrm{O}$ and $\delta^{18} \mathrm{O}_{\mathrm{atm}}$ wiggle matching to the Huascarán ice core record [Thompson et al., 1995]. To obtain dating of the bottom part for core B, six horizons of volcanic eruptions, the tritium peak [Knüsel et al., 2003] and radiocarbon dates $(n=6)$ obtained by using the same technique as described for the Colle Gnifetti core were fit with the two parameter model described in section 2.3 [Kellerhals, 2008]. The dating of core A and B each based on a different method as described before (wiggle matching and radiocarbon dating, respectively) agrees reasonably well. Over the time period from 10 to $13 \mathrm{ka}$ B.P., dating matches within less than 1000 years with the $1 \sigma$ ranges of the four corresponding ${ }^{14} \mathrm{C}_{\mathrm{cal}}$ ages increasing from \pm 480 to \pm 1450 years.

[16] Considering the above results, an offset of the Colle Gnifetti radiocarbon dates shifted toward younger ages by several thousand years as it might be implied by the record of the stable isotopes of water can be excluded.

\section{Discussion and Conclusion}

[17] The extension of mountain glaciers in the Alps since the Last Glacial Maximum (LGM) around 20,000 years ago was smallest during the warmest time of the Holocene, the so-called Climatic Optimum around 7-6 ka B.P. [Davis et al., 2003; Ganopolski et al., 1998; Thompson et al., 2006]. Recent findings such as the Ötztal Ice Man (3280 m asl, Hauslabjoch, Italian/Austrian Alps) [Baroni and Orombelli, 1996] and ice-covered prehistoric artifacts (2756 m asl, Schnidejoch, Swiss Alps) [Grosjean et al., 2007] suggest that the present state of glaciers in the Alps is comparable to this period. Our observation of ice likely more than $10 \mathrm{ka}$ old at the Colle Gnifetti indicates that at higher-altitude permanent ice coverage was preserved throughout the Holocene. For glaciers frozen to bedrock with a complex topography, one might expect a shear zone between the basal ice and the active layer on top, resulting in a hiatus in the age-depth relation. The finding of a continuous increase of age with depth even in the deepest part is remarkable. Our results imply, that a first Alpine climate record from an European glacier archive covering the entire Holocene is accessible, allowing for a comparison of the Climatic Optimum warm period with today's climate and atmospheric conditions.

[18] The new radiocarbon dating technique described should have wide impact on paleoclimate research. It represents an additional, independent and new dating tool with great potential for applications in ice core studies, due to its ability of improving and extending new and already existing chronologies. Using ice of known age (Nevado Illimani), the dating accuracy of the method could be confirmed in a first validation attempt. However, further efforts to improve the validation are still needed. This is also due to the fact that there is potential to reach higher precision (smaller uncertainties) in future studies. As a result of future applications of the method to a number of ice cores and ice samples from different sites (some of them preferentially dated independently) and the ongoing development in AMS technology these goals can certainly be achieved. A very important step forward was made in the recent past when AMS analysis of gaseous $\mathrm{CO}_{2}$ for radiocarbon dating was made possible [e.g., Ruff et al., 2007, 2009]. Already, this could be applied for some of the samples presented in this study. Such measurements benefit from a reduced sample preparation time due to fewer preparation steps required, what as a consequence decreases the number of potential contamination sources. Higher analytical precision and a smaller amount of carbon (carbonaceous particles) needed also allows the use of smaller, i.e., shorter ice sections resulting in a physically better defined (narrower) age horizon.

[19] Acknowledgments. We thank Edith Vogel and Leonhard Tobler for ${ }^{20} \mathrm{~Pb}$ dating; Jost Eikenberg for tritium; Andreas Laube for stable isotope analysis; and the drilling team, Paolo Gabrielli, Frederic Planchon, Beat Rufibach, Aurel Schwerzmann, Margit Schwikowski, and Dieter Stampfli, for recovery of an ice core with excellent quality. This study was partly funded by the NCCR Climate project of the Swiss National Science Foundation (projects VITA and VIVALDI), the EU FP6 project MILLENNIUM (017008), and the Istituto Nazionale per la Ricerca Scientifica e Tecnologica sulla Montagna (INRM).

\section{References}

Baroni, C., and G. Orombelli (1996), The Alpine "Iceman" and Holocene climatic change, Quat. Res., 46, 78-83, doi:10.1006/qres.1996.0046.

Bender, M., T. Sowers, M.-L. Dickson, J. Orchardo, P. Grootes, P. A Mayewski, and D. A. Meese (1994), Climate correlations between Greenland and Antarctica during the past 100,000 years, Nature, 372, 663-666, doi: $10.1038 / 372663 \mathrm{a} 0$.

Bronk Ramsey, C. (2001), Development of the radiocarbon program OxCal, Radiocarbon, 43(2A), 355-363.

Bronk Ramsey, C. (2005), Improving the resolution of radiocarbon dating by statistical analysis, in The Bible and Radiocarbon Dating: Archaeology, Text and Science, edited by T. E. Levy and T. F. Higham, pp. 57-64, Equinox, London.

Brook, E. J. (2005), Tiny bubbles tell all, Science, 310(5752), 1285-1287, doi:10.1126/science. 1121535 .

Cecil, L. D., J. R. Green, and L. G. Thompson (Eds.) (2004), Earth Paleoenvironments: Records Preserved in Mid- and Low-Latitude Glaciers, vol. 9, Kluwer Acad., Dordrecht, Netherlands.

Cole-Dai, J., E. Mosley-Thompson, S. P. Wight, and L. G. Thompson (1997), Annually resolved Southern Hemisphere volcanic history from two Antarctic ice cores, J. Geophys. Res., 102(D14), 16,761-16,771, doi:10.1029/97JD01394.

Davis, B. A. S., S. Brewer, A. C. Stevenson, and J. Guiot (2003), The temperature of Europe during the Holocene reconstructed from pollen data, Quat. Sci. Rev., 22, 1701-1716, doi:10.1016/S02773791(03)00173-2.

Eichler, A., M. Schwikowski, H. W. Gäggeler, V. Furrer, H.-A. Synal, J. Beer, M. Sauer, and M. Funk (2000), Glaciochemical dating of an ice core from the upper Grenzgletscher (4200 $\mathrm{m}$ a.s.1.), J. Glaciol., 46 , 507-515, doi:10.3189/172756500781833098.

EPICA Community Members (2004), Eight glacial cycles from an Antarctic ice core, Nature, 429, 623-628, doi:10.1038/nature02599.

Gäggeler, H. W., H. R. von Gunten, E. Rössler, H. Oeschger, and U. Schotterer (1983), ${ }^{210} \mathrm{~Pb}$ dating of cold alpine firn/ice cores from Colle Gniffetti, J. Glaciol., 29(101), 165-177.

Ganopolski, A., C. Kubatzki, M. Claussen, V. Brovkin, and V. Petoukhov (1998), The influence of vegetation-atmosphere-ocean interaction on climate during the mid-Holocene, Science, 280, 1916-1919, doi:10.1126/ science. 280.5371 .1916 .

Grosjean, M., P. J. Suter, M. Trachsel, and H. Wanner (2007), Ice-born prehistoric finds in the Swiss Alps reflect Holocene glacier fluctuations, J. Quat. Sci., 22, 203-207, doi:10.1002/jqs.1111.

Jenk, T. M., S. Szidat, M. Schwikowski, H. W. Gäggeler, S. Brütsch, L. Wacker, H.-A. Synal, and M. Saurer (2006), Radiocarbon analysis in an Alpine ice core: Record of anthropogenic and biogenic contributions to carbonaceous aerosols in the past (1650-1940), Atmos. Chem. Phys., 6, 5381-5390.

Jenk, T. M., S. Szidat, M. Schwikowski, H. W. Gäggeler, D. Bolius L. Wacker, H.-A. Synal, and M. Saurer (2007), Microgram level 
radiocarbon $\left({ }^{14} \mathrm{C}\right)$ determination on carbonaceous particles in ice, $\mathrm{Nucl}$. Instrum. Methods Phys. Res., Sect. B, 259, 518-525, doi:10.1016/ j.nimb.2007.01.196.

Keck, L. (2001), Climate significance of Alpine ice core stable isotope records, Ph.D. thesis, Inst. für Umweltphysik, Univ. Heidelberg, Heidelberg, Germany. (Available at http://archiv.ub.uni-heidelberg.de/ volltextserver/volltexte/2002/1837/pdf/summary.pdf)

Kellerhals, T. (2008), Holocene climate fluctuations in tropical South America deduced from an Illimani ice core, Ph.D. thesis, Univ. of Bern, Bern.

Knüsel, S., P. Ginot, U. Schotterer, M. Schwikowski, H. W. Gäggeler, B. Francou, J. R. Petit, J. C. Simões, and J. D. Taupin (2003), Dating of two nearby ice cores from the Illimani, Bolivia, J. Geophys. Res., 108(D6), 4181, doi:10.1029/2001JD002028.

Lavanchy, V. M. H., H. W. Gäggeler, U. Schotterer, M. Schwikowski, and U. Baltensperger (1999), Historical record of carbonaceous particle concentrations from a European high-alpine glacier (Colle Gnifetti, Switzerland), J. Geophys. Res., 104(D17), 21,227-21,236.

McConnell, J. R., R. Edwards, G. L. Kok, M. G. Flanner, C. S. Zender, E. S. Saltzman, J. R. Banta, D. R. Pasteris, M. M. Carter, and J. D. W. Kahl (2007), 20th century industrial black carbon emissions altered Arctic climate forcing, Science, 317(5843), 1381-1384, doi:10.1126/ science. 1144856.

North Greenland Ice Core Project members (2004), High-resolution record of Northern Hemisphere climate extending into the last interglacial period, Nature, 431(7005), 147-151, doi:10.1038/nature02805.

Ramirez, E., et al. (2003), A new Andean deep ice core from Nevado Illimani (6350 m), Bolivia, Earth Planet. Sci. Lett., 212(3-4), 337-350, doi:10.1016/S0012-821X(03)00240-1.

Rasmussen, S. O., et al. (2006), A new Greenland ice core chronology for the last glacial termination, J. Geophys. Res., 111, D06102, doi:10.1029/ 2005JD006079.

Reimer, P. J., et al. (2004), INTCAL04 terrestrial radiocarbon age calibration, 0-26 Cal kyr BP, Radiocarbon, 46, 1029-1058.

Ruff, M., L. Wacker, H. W. Gäggeler, M. Suter, H.-A. Synal, and S. Szidat (2007), A gas ion source for radiocarbon measurements at $200 \mathrm{kV}$, Radiocarbon, 49(2), 307-314.

Ruff, M., H. W. Gäggeler, M. Suter, H.-A. Synal, S. Szidat, and L. Wacker (2009), Gaseous radiocarbon measurements of small samples, Nucl. Instrum. Methods Phys. Res., Sect. B, in press.

Schwikowski, M. (2004), Reconstruction of European air pollution from Alpine ice cores, in Earth Paleoenvironments: Records Preserved in Midand Low-Latitude Glaciers, edited by L. D. Cecil, J. R. Green, and L. G. Thompson, pp. 95-119, Kluwer Acad., Dordrecht, Netherlands.

Schwikowski, M., P. Seibert, U. Baltensperger, and H. W. Gäggeler (1995), A study of an outstanding Saharan dust event at the high-alpine site Jungfraujoch, Switzerland, Atmos. Environ., 29, 1829-1842, doi:10.1016/1352-2310(95)00060-C.

Smith, J. A., G. O. Seltzer, D. L. Farber, D. T. Rodbell, and R. C. Finkel (2005), Early local last glacial maximum in the tropical Andes, Science, 308, 678, doi: $10.1126 /$ science. 1107075 .

Steffensen, J. P., et al. (2008), High resolution Greenland ice core data show abrupt climate change happens in few years, Science, 321(5889), 680-684, doi:10.1126/science.1157707.

Stuiver, M., and H. A. Polach (1977), Discussion: Reporting of C-14 data, Radiocarbon, 19, 355-363.

Synal, H.-A., S. Jacob, and M. Suter (2000), The PSI/ETH small radiocarbon dating system, Nucl. Instrum. Methods Phys. Res., Sect. B, 172, 1-7, doi:10.1016/S0168-583X(00)00376-1.
Synal, H.-A., M. Stocker, and M. Suter (2007), MICADAS: A new compact radiocarbon AMS system, Nucl. Instrum. Methods Phys. Res., Sect. $B, 259(1), 7-13$, doi:10.1016/j.nimb.2007.01.138.

Szidat, S., T. M. Jenk, H. W. Gäggeler, H.-A. Synal, I. Hajdas, G. Bonani, and M. Saurer (2004a), THEODORE, a two-step heating system for the EC/OC determination of radiocarbon $\left({ }^{14} \mathrm{C}\right)$ in the environment, Nucl. Instrum. Methods Phys. Res., Sect. B, 223-224, 829-836, doi:10.1016/j.nimb.2004.04.153.

Szidat, S., et al. (2004b), Source apportionment of aerosols by ${ }^{14} \mathrm{C}$ measurements in different carbonaceous particle fractions, Radiocarbon, 46, $475-484$.

Szidat, S., T. M. Jenk, H.-A. Synal, M. Kalberer, L. Wacker, I. Hajdas, A. Kasper-Giebl, and U. Baltensperger (2006), Contributions of fossil fuel, biomass burning, and biogenic emissions to carbonaceous aerosols in Zürich as traced by ${ }^{14} \mathrm{C}, J$. Geophys. Res., 111, D07206, doi:10.1029/2005JD006590.

Thompson, L. G. (1996), Climate changes for the last 2000 years inferred from ice core evidence in tropical ice cores, in Climate Variations and Forcing Mechanisms of the Last 2000 Years, NATO ASI Ser., Ser. I, vol. 41, edited by P. D. Jones, R. S. Bradley, and J. Jouzel, pp. 281-297, Springer, Berlin.

Thompson, L. G., E. Mosley-Thompson, M. E. Davis, J. F. Bolzan, J. Dai, L. Klein, N. Gundestrup, T. Yao, X. Wu, and Z. Xie (1990), Glacial stage ice-core records from the subtropical Dunde ice cap, China, Ann. Glaciol., 14, 288-297.

Thompson, L. G., E. Mosley-Thompson, M. E. Davis, P.-N. Lin, K. A. Henderson, J. Cole-Dai, J. F. Bolzan, and K.-B. Liu (1995), Late glacial stage and Holocene tropical ice core records from Huascaran, Peru, Science, 269, 46-50, doi:10.1126/science.269.5220.46.

Thompson, L. G., et al. (1998), A 25,000-year tropical climate history from Bolivian ice cores, Science, 282, 1858-1864, doi:10.1126/ science.282.5395.1858.

Thompson, L. G., T. Yao, E. Mosley-Thompson, M. E. Davis, K. A. Henderson, and P.-N. Lin (2000), A high resolution millennial record of the South Asian Monsoon from Himalayan ice cores, Science, 289, 1916-1919, doi:10.1126/science.289.5486.1916.

Thompson, L. G., E. Mosley-Thompson, H. Brecher, M. E. Davis, B. Leon, D. Les, T. A. Mashiotta, P.-N. Lin, and K. Mountain (2006), Abrupt tropical climate change: Past and present, Proc. Natl. Acad. Sci. U. S. A., 103(28), 10,536-10,543, doi:10.1073/pnas.0603900103.

Vinther, B. M., et al. (2006), A synchronized dating of three Greenland ice cores throughout the Holocene, J. Geophys. Res., 111, D13102, doi: $10.1029 / 2005$ JD006921.

C. Barbante, Environmental Sciences Department, University of Venice, I-30123 Venice, Italy.

D. Bolius and M. Schwikowski, Paul Scherrer Institut, CH-5232 Villigen PSI, Switzerland.

C. F. Boutron, Laboratoire de Glaciologie et Géophysique de l'Environnement, UMR 5183, University Joseph Fourier of Grenoble, CNRS, Domaine Universitaire, F-38402 Saint-Martin-d'Hères CEDEX, France.

H. W. Gäggeler, M. Ruff, M. Sigl, and S. Szidat, Department of Chemistry and Biochemistry, University of Bern, CH-3012 Bern, Switzerland.

T. M. Jenk, Centre for Ice and Climate, Niels Bohr Institute, University of Copenhagen, DK-2100 Copenhagen, Denmark. (tjenk@gfy.ku.dk)

L. Wacker, Institute for Particle Physics, ETH Zurich, CH-8093 Zurich, Switzerland. 